\title{
Nutraceutical Supplements in the Management and Prevention of Osteoarthritis
}

\author{
Paola Castrogiovanni ${ }^{1}$, Francesca Maria Trovato ${ }^{2}$, Carla Loreto ${ }^{1}$, Houda Nsir ${ }^{3}$, \\ Marta Anna Szychlinska ${ }^{1}$ and Giuseppe Musumeci ${ }^{1, *}$ \\ 1 Department of Biomedical and Biotechnological Sciences, Human Anatomy and Histology Section, \\ School of Medicine, University of Catania, 95100 Catania, Italy; pacastro@unict.it (P.C.); \\ carla.loreto@unict.it (C.L.); marta.sz@hotmail.it (M.A.S.) \\ 2 Department of Clinical and Experimental Medicine, University of Catania, 95100 Catania, Italy; \\ trovatofrancesca@gmail.com \\ 3 Department of Molecular and Cellular Biology and Plant Physiology, Centre of Biotechnology of \\ Borj Cedreya, University of Carthage, Carthage 2050, Tunisia; houda.nsir@gmail.com \\ * Correspondence: g.musumeci@unict.it; Tel.: +39-095-378-2043; Fax: +39-095-378-2044
}

Academic Editor: Irmgard Tegeder

Received: 19 October 2016; Accepted: 30 November 2016; Published: 6 December 2016

\begin{abstract}
Nutraceuticals are dietary compounds which have a role in the balance of anabolic and catabolic signals in joints. Their regulatory function on homeostasis of cartilage metabolism nutraceuticals is increasingly considered for the management and, above all, the prevention of osteoarthritis (OA). OA is a degenerative disease characterized by cartilage and synovium inflammation that can cause joint stiffness, swelling, pain, and loss of mobility. It is a multifactorial disease and, due to the great percentage of people suffering from it and the general increase in life expectancy, OA is considered as one of the most significant causes of disability in the world. OA impairs the structural integrity of articular cartilage that greatly depends on a balance between the anabolic and catabolic processes which occur in chondrocytes and synovial fluid of the joints, therefore the integration with nutraceutical compounds in diet increases the treatment options for patients with established OA beyond traditional rehabilitation, medications, and surgical strategies. In our review, with respect to the current literature, we highlight some of many existing nutraceutical compounds that could be used as integrators in a daily diet thanks to their easy availability, such as in olive oil, fish oil, and botanical extracts used as non-pharmacologic treatment.
\end{abstract}

Keywords: nutraceuticals; osteoarthritis; prevention; diet

\section{Introduction}

Osteoarthritis (OA) is a degenerative disease characterized by cartilage and synovium inflammation that can cause joint stiffness, swelling, pain, and loss of mobility [1-3]. OA is a very complex and multifactorial disease. Due to the high percentage of people suffering from this disease, with a greater percentage in women after menopause $(18 \%)$ than in men $(9.6 \%)$, and the increase in life expectancy, OA is considered one of the most significant causes of disability in the world [4-7]. Although OA mainly affects the joints of knees, hands, and hips [8], it also results in alterations in other joint tissues such as ligaments, synovium and subchondral bone [9]. OA impairs the structural integrity of articular cartilage that greatly depends on a balance between anabolic and catabolic processes, which occur in chondrocytes and synovial fluid of the joints $[10,11]$. Nutraceuticals are dietary compounds that, from data in literature, seem to play a role in these processes within articular cartilage [12]. Although there are many papers in the scientific literature concerning the use of a great variety of nutraceuticals as an alternative treatment of $\mathrm{OA}$, the aim of our descriptive review is to highlight the importance of non-invasive strategies in the treatment of OA through the use of the most common 
and easily available nutraceuticals, such as olive oil, fish oil, and botanical extracts. The integration with nutraceutical compounds in diet increases the treatment options for patients with established OA beyond the traditional rehabilitation, medications, and surgical strategies such as non-pharmacologic treatment [13].

\section{Micro and Macroscopic Features in Early and Severe Osteoarthritis (OA)}

$\mathrm{OA}$ is characterized by impairments in the structure and functionality of joint cartilage in consequence of an imbalance between anabolic and catabolic processes in the cartilage tissue that could cause its degradation; if cartilage degradation exceeds reparative processes, the OA goes on and advances [14,15] (Figure 1). This degenerative disease is characterized by several changes (narrowed joint space, thickening, formation of osteophytes, and cysts in the subchondral bone) that are radiographically visible, even if radiographs do not indicate the degree of cartilage degeneration [16]. It is possible to detect osteophytes also through magnetic resonance imaging (MRI), that allow us also to detect geodes or subchondral cysts in advanced stages of OA [17]. Microscopic alterations in joint cartilage are evaluated by the Mankin [18] score or a modified version by Sakakibara et al. [19], that consider several factors such as cell morphology, extracellular matrix staining, and appearance of the tidemark. The highest scores highlighting the most severe damage of joint tissues are 14 for the Mankin score and 32 for the modified Mankin score. Alterations to healthy joint cartilage usually do not exceed grades of 1-3 [20]. Histological grading criteria of Kraus' modified Mankin score [18,21] and histopathology OARSI system [22,23] are used as semi-quantitative methods.

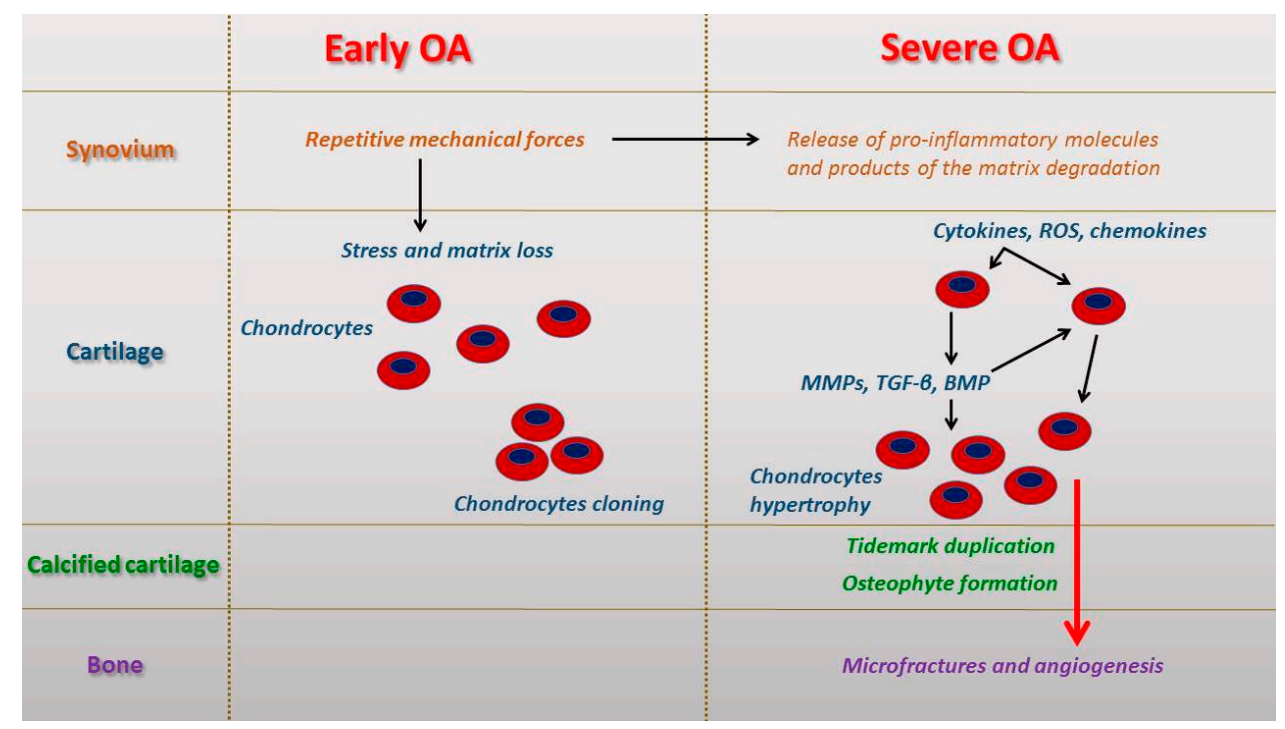

Figure 1. Early and severe osteoarthritis (OA) causes and molecular events in the different tissues involved in the joints. BMP: Bone morphogenetic proteins; MMPs: Matrix metalloproteinases; ROS: Reactive oxygen species; TGF- $\beta$ : Transforming growth factor $\beta$.

Cartilage is mainly composed of collagen type II and the proteoglycan aggrecan and it is characterized by viscoelastic and compressive properties thanks to the extracellular matrix [24-27]. Healthy joint cartilage has a smooth surface and it is white, shiny, and elastic. In OA, cartilage instead shows a dull and irregular surface with discoloration and softening and more synovial fluid may be produced, with newly invaded blood vessels [28]. In particular, at the early stage of degeneration, minimal changes are detected in the cartilage surface in which glycosaminoglycans remain homogenously distributed; as the disease progresses, there is a loss of proteoglycans, and in severe OA the cartilage surface is rough and broken by fissures and cracks [16]. 
In healthy joint cartilage, four layers are recognizable: superficial zone, middle zone, deep zone, and calcified zone. In the superficial zone, cells are flat and spindle-shaped, parallel to the joint surface $[14,26]$. The superficial zone contains the majority of collagen fibers, parallel to the surface, which results in high tensile modulus to resist shear stress at the joint surface [14]. In early OA, mild fibrillations are found in the superficial zone [16] and cartilage presents thickening, a consequence of hypertrophy. As the disease advances, cells of the intermediate and radial zone show mild to moderate hypercellularity; necrotic chondrocytes with pyknotic nuclei in the intermediate and radial zone are found; the synovial membrane includes hyperplasia of synovial lining cells, thickening of the synovial membrane, infiltration of inflammatory cells, and fibrosis [14,29]. In severe OA, the cartilage shows extensive degeneration: hypertrophic villi and full-thickness defect areas can be seen where the cartilage is missing completely and the subchondral bone is exposed; the subchondral plate itself is thicker and more dense; cells are arranged in clusters especially around fissures or disappear completely as the disease progresses; the cartilage is replaced by fibrocartilaginous, scar-like tissue with fibroblast-like cells $[16,28]$. In other cases, full-thickness defects develop, where the bone lacks the cartilage completely; the loss of proteoglycan content reaches the deep zones; the tidemark becomes unclear and finally is invaded by blood vessels from the subchondral bone, which penetrate into the calcified zone [28]. Osteophytes are found in early stages of the diseases, but become more pronounced in advanced stages of OA. The rate of OA progression depends on species and joint localization, and the extent of damage could be dependent on the joint area, which can be explained by different loading conditions in distinct regions [28].

Articular cartilage is not vascularized nor innervated, so nutrients and cellular repair molecules are transported to the chondrocytes by diffusion from the synovial fluid. Thus, articular cartilage has limited capacities for self-regeneration and, in OA, shows reduced mechanical capacities compared to healthy cartilage [30]. Chondrocytes are very active cells but they normally do not divide, so only small defects associated with minimal loss of matrix components can be repaired by regeneration; if more wide defects exceed the repair capacity, the damage can become permanent [14]. Because OA involves progressive loss of the structure and functionality of articular cartilage due to an imbalance between anabolic and catabolic processes in the cartilage tissue, preventive and therapeutic interventions are necessary to prevent $\mathrm{OA}$ and/or improve the regeneration capacities of joint cartilage [30].

\section{Nutraceuticals}

\subsection{Fish Oil}

The effectiveness and precise benefits of fish oil intake in patients with OA are still far from well understood. In fact, in vitro and in vivo studies showed a dose-dependent decrease in induced inflammatory destruction of cartilage tissue associated with fish oil supplementation [31]. Proposed mechanisms for the anti-inflammatory actions of n-3 fatty acids, eicosapentaenoic acid (EPA), and docosahexaenoic acid (DHA) from fish oil include competition with n-6 fatty acids; the EPA and DHA derived anti-inflammatory molecules called resolvins; the competition for receptors of $n-3$ products with proinflammatory molecules; the reduction in gene expression of cytokines, cyclo-oxygenase 2 , and degrading proteinases; the interference in the signaling pathways of inflammation; and the reduction in lymphocyte proliferation [31]. The lack of human clinical trials showing the effects of fish oil supplementation in patients with OA is probably the most relevant hindrance to fish oil being routinely recommended [31]. Recently, a clinical trial by Hill and colleagues, demonstrating a better performance of low versus high doses of fish oil supplementation [32], provoked another heated debate on the effective utility of this compound [33].

\subsection{GAGs (Glucosamine Sulfate, Chondroitin Sulfate, and Hyaluronic Acid)}

As is well known that hyaluronic acid, glucosamine sulfate, and chondroitin sulfate are glycosaminoglycans (GAGs) synthesized by chondrocytes and synoviocytes, and are basic components 
of the extracellular matrix and synovial fluid. GAGs can also be introduced with food, thus there is a growing interest towards the nutritional supplementation of these molecules, to protect the joints from possible alterations caused by trauma or wear and, therefore, for OA prevention [34]. From clinical and preclinical data, supplementation of glucosamine sulfate seems to improve joint function and reduce pain and also appears to stimulate cartilage regeneration, thus inducing a regression of OA [34]. Although not all the related papers are in agreement and in many clinical trials there is a large number of subjects who did not benefit from treatment with glucosamine, an advantage of this treatment is that glucosamine has low and rare adverse effects so that it could represent a viable option for the management of OA [35]. In two randomized controlled trials, glucosamine sulfate, as well as chondroitin sulfate, mitigated the catabolic and degenerative processes thanks to their anti-inflammatory and antioxidant properties [36,37]. A pharmacokinetic study, however, suggests that the simultaneous ingestion of glucosamine and chondroitin sulfate has no synergic effect due to the competition between the two molecules in intestinal absorption [38]. Therefore, the therapeutic indication is to prevent their co-ingestion and to use different times of ingestion per day with appropriate dosages, taking into account the individual clinical cases [39]. However, other authors evidenced that glucosamine and chondroitin sulfate alone or in combination did not reduce pain in the overall examined group of patients with knee OA and that exploratory analyses suggested this kind of treatment only in a subgroup of patients with moderate-to-severe knee pain [40]. According to other authors, the optimal use of glucosmine sulfate and chondroitin sulfate to improve the status of the pain and stiffness is achieved by further integration with $n-3$ fatty acids eicosapentaenoic acid (EPA) and docosahexaenoic acid (DHA) from fish oil [35,41]. Additionally, hyaluronic acid (HA), another GAG, has beneficial properties on the joints. In vitro, it improves the mechanical properties of the synovial fluid and has a biochemical regulatory role on joint tissues [42]. HA is usually used in clinical contexts through local injections in the joint, with a reduction in pain and improvement in function [43]. Many authors also suggest oral use of HA that is absorbed in the intestine and released into joint tissues [44]. The results of improvement obtained with WOMAC scores are encouraging, although further research is needed to identify any long-term positive results [39].

\subsection{Olive Oil}

Olive oil is the principal fat and one of the cornerstones of the Mediterranean diet. The anti-inflammatory properties of olive oil are attributed to its phytochemicals, such as the phenolic compounds and monounsaturated fatty acids (MUFAs) [27]. In rats, it was demonstrated that an olive oil supplemented diet improves cartilage recovery after anterior cruciate ligament transection [27]. Only one double blinded, randomized clinical trial in the literature demonstrated that the topical application of olive oil improved pain and physical function in patients affected by knee osteoarthritis, confirming the utility of the traditional methods used in some rural areas of Iran [45]. Also in this case, the lack of clinical trials demonstrating the effect of olive oil supplementation with diet limits the recommendation of this compound.

\subsection{Methionine}

Methionine is an essential amino acid for humans, since the human organism is not able to synthesize it and therefore it is taken with the diet. The active form of methionine is $S$-adenosylmethionine (SAMe) is a precursor of glutathione. SAMe has antioxidant properties and, in the joints, provides levels of glutathione peroxidase, an antioxidant enzyme [46]. In addition, SAMe inhibits enzymes that degrade the cartilage protecting its proteins and proteoglycans [39]. Some researchers show that SAMe promotes anabolic processes of cartilage, thus having a regulatory function in cartilage regeneration [47]. It was also shown that, in patients with OA, treatment with SAMe has a more beneficial effect in the long term compared to treatment with nonsteroidal anti-inflammatory drugs (NSAIDs) [48], even if in some clinical trials SAMe was found to be equally effective as the NSAID and more effective than placebo for pain and function $[49,50]$. SAMe has proven to be an even 
more effective supplement in patients with OA and with liver or kidney diseases characterized by a difficulty in the metabolic activation of methionine [39]. Usually, the use of SAMe envisages a dose of 800-1600 mg per day and the indication of a sufficient intake of folate and vitamin B [39].

\subsection{Undenatured Type II Collagen}

Undenatured type II collagen (UC-II) is a nutritional supplement derived from chicken sternum cartilage [49]. Data in the literature show that the treatment of OA patients with UC-II increases the mobility and the functionality of the joints and reduces pain [49-52]. In an animal model, UC-II influences the humoral and cellular immune response through the T-regulatory cell secreting cytokines such as IL-10 and transforming growth factor- $\beta$ which inhibit the immune response to collagen type II present in the extracellular matrix of the articular cartilage [53,54]. Treatment with UC-II prevents, therefore, the proinflammatory overreaction of the immune system against the articular cartilage in patients with OA [39].

\subsection{Botanical Extracts}

Botanical extracts are a large variety of substances obtained from plants and used as additives in diet.

Avocado/soy unsaponifiable (ASU) components are a sterol-rich hydrolyzed lipid fraction extract from avocado and soybean. ASU has anabolic and anti-inflammatory properties on chondrocytes, indeed in vitro ASU inhibits inflammatory cytokines such as IL-1, IL-6, IL-8, and prostaglandin E2 [55]. Moreover, ASU stimulates transforming growth factor production, collagen, and aggrecan synthesis [56]. In treatment of OA, the use of $300 \mathrm{mg}$ per day of ASU determines an improvement of OA symptoms, even if further research is necessary to better understand the role of ASU in managing $\mathrm{OA}$ and disease progression in the long term [39].

Curcumin is extracted from the Indian spice turmeric, it is an aromatic molecule with an anti-inflammatory effect that in vitro studies showed to inhibit the activity of COX-2 and 5-LOX enzyme, thus protecting chondrocytes from the negative effects of IL- $1 \beta[57,58]$. Data from literature also show in vitro a possible synergic effect of curcumin with capsaicin or resveratrol by regulating signaling of both nuclear factor- $\mathrm{KB}$ and IL-1 $\beta$ and modulating the activity of collagenase, hyaluronidase, and elastase, thus favoring the integrity of the extracellular matrix of cartilage and the differentiation and survival of chondrocytes [59]. Moreover, in vitro data show a synergistic effect of curcumin with the n-3 polyunsaturated fatty acids (PUFA)s, EPA and DHA, in enhancing antioxidant and inflammatory cytokine modulation [60]. Lastly, curcumin seems to be well tolerated at doses of 2-10 g daily, even if it should be used with caution in individuals on antiplatelet and anticoagulation therapy [39].

The oleoresin from the Boswellia serrata tree is rich in boswellic acids, which exhibit an anti-inflammatory behavior by inhibiting leukotriene synthesis by inhibiting the activity of the enzyme 5-lipoxygenase through a non-redox reaction [61]. Data from literature show and support the potential of Boswellia serrata oleoresin for the treatment of several inflammatory diseases including RA, OA, and asthma [39]. However, in relation to its anti-inflammatory mechanism, scientific data hypothesize that the higher levels of boswellic acids may modulate inflammation via prostaglandin E synthase-1 and the serine protease cathepsin G, rather than 5-lipoxygenase inhibition [62]. From randomized clinical trials, oleoresin from Boswellia serrata seems to improve the status of pain, mobility, and swelling in patients with knee OA $[39,63]$. However, the real effect of oleoresin from Boswellia serrata is still difficult to determine $[39,64]$.

Phytoflavonoids and bioflavonoids are polyphenols extracted from plants and vegetables with strong anti-inflammatory and free-radical scavenging antioxidant properties [65-68]. In vitro and in vivo studies highlight that they can influence some of the metabolic and biochemical processes causing the development and progression of OA such as inhibition of the production of proinflammatory cytokines, including IL- $1 \beta$, TNF- $\alpha$, IL-6, and prostaglandin E2 in affected 
joints [69-71]. Moreover, in vivo, many flavonoids seem suppress inducible nitric oxide synthase, inhibiting the production of nitric oxide and neutralizing other reactive nitrogen species (RNS) and reactive oxygen species (ROS), such as superoxide [72,73] that are involved in promoting inflammatory gene expression [74]. Clinical efficacy, in OA, of phytoflavonoids and bioflavonoids is nowadays considered, in fact some authors showed improvements in WOMAC (Western Ontario and Mc Master University) OA index scores and joint function, with a low toxicity and a good safety profile [75,76].

Harpagophytum procumbens is a South African plant known as devil's claw. In its extract, harpagosides-triterpene glycoside compounds are present which have been shown may reduce the IL-1 $\beta$-induced production of matrix metalloproteinases (MMP)-1, MMP-3, and MMP-9 in chondrocytes, and downregulate TNF- $\alpha$ and COX-2 gene expression in vitro $[77,78]$. The use of devil's claw extract as a dietary supplement in the treatment of hip and knee OA patients seems to be effective, also thanks to its safety profile and low adverse effects such as diarrhea and flatulence [79-81].

Bromelain is extracted from stems and immature fruits of pineapple and it contains proteolytic enzymes that may have anti-inflammatory, analgesic, antithrombotic, and antifibrinolytic properties [82]. Several clinical trials used bromelain in treatment of knee OA, with mixed and uncertain results $[82,83]$, so that it is difficult, at this time, to give some indications in relation to its use in treatment of $\mathrm{OA}$ and more rigorous clinical trials are necessary.

Lastly, ginger is an anti-inflammatory and antirheumatic agent used in holistic medicine, and it contains bioactive molecules such as gingerols and shogaols [84]. In vitro, it has been shown that ginger extract suppressed TNF- $\alpha$ and inhibited COX-2-mediated synthesis of proinflammatory cytochines [85]. Some authors demonstrated, in clinical trials, dose-dependent improvements in the WOMAC index and visual analog scale pain profiles for knee OA, thanks to ginger extracts [86-88].

\section{Conclusions}

The management and treatment of $\mathrm{OA}$ is based on the use of anti-inflammatory agents and analgesics, surgical procedures, and rehabilitation to enable healthy body weight, lifestyle, and physical activity. However, nutritional intervention represents an ongoing strategy for managing and preventing OA as a complement to traditional clinical treatment. Nutritional interventions could regulate the balance between anabolic and catabolic processes in joint tissue, influencing immune response, redox balance, and free-radical scavenging, thus providing for structural precursors of synovial fluid and extracellular matrix of cartilage (Table 1). Many of the nutraceuticals that we describe in our review, such as GAGs and botanical extracts, show beneficial effects on joints so that nutraceutical intervention is, nowadays, considered a strategic tool for managing and preventing OA, given its risk-benefit ratio and low cost. Moreover, scientific data demonstrate that this kind of strategy supports not only clinical symptoms and functional improvement, but it could determine a regression of the disease. Although in the scientific literature there are many papers that deal with alternative treatments in the management of $\mathrm{OA}$, the aim of our descriptive review is to highlight the importance of non-invasive strategies in the treatment of OA, like non-pharmacologic therapy, through the use of the most common nutraceuticals, particularly less severe forms of the disease. 
Table 1. Potential role of nutraceuticals in osteoarthritis. Potential role: none "- "; low "+"; moderate "++"; high "+++".

\begin{tabular}{|c|c|c|c|c|c|c|}
\hline \multirow[b]{2}{*}{ Analyzed Articles } & \multirow[b]{2}{*}{ Nutraceuticals } & \multicolumn{5}{|c|}{ Potential Role } \\
\hline & & Antiinflammatory & $\begin{array}{c}\text { Redox } \\
\text { Balance/Antioxidant }\end{array}$ & Anabolic & Anticatabolic & $\begin{array}{l}\text { Structural } \\
\text { Substrates }\end{array}$ \\
\hline $\begin{array}{l}\text { Boe and Vangsness; Am. J. Orthop. 2015, 44, 302-305. } \\
\text { Hill et al.; Ann. Rheum. Dis. 2016, 75, 23-29. } \\
\text { Gao et al.; Ann. Rheum. Dis. 2016, 75, e13. } \\
\text { Lopez; PM R 2012, 4, S155-S168. }\end{array}$ & $\begin{array}{c}\text { Fish Oil EPA + DHA } \\
(2-4 \mathrm{~g} / \text { day })\end{array}$ & +++ & - & - & +++ & ++ \\
\hline $\begin{array}{l}\text { Kirkham and Samarasinghe; J. Orthop. Surg. 2009, 17, 72-76. } \\
\text { Michel et al.; Arthritis Rheum. 2005, 52, 779-786. } \\
\text { Kahan et al.; Arthritis Rheum. 2009, 60, 524-533. } \\
\text { Jackson et al.; Osteoarthr. Cartil. 2010, 19, 297-302. } \\
\text { Lopez; PM R 2012, 4, S155-S168. } \\
\text { Gruenwald et al.; Adv. Ther. 2009, 26, 858-871. } \\
\text { Maneiro et al.; Clin. Exp. Rheumatol. 2004, 22, 307-312. } \\
\text { Adams et al.; Drug Saf. 2000, 23, 115-130. } \\
\text { Balogh et al.; J. Agric. Food Chem. 2008, 56, 10582-10593. }\end{array}$ & $\begin{array}{l}\text { GAGs glucosamine sulfate } \\
(20 \mathrm{mg} / \mathrm{kg} \text { body } \\
\text { weight/day); chondroitin } \\
\text { sulfate }(1200 \mathrm{mg} / \mathrm{d}) \\
\text { hyaluronic acid } \\
(50-100 \mathrm{mg} / \mathrm{d})\end{array}$ & + & + & ++ & +++ & +++ \\
\hline $\begin{array}{l}\text { Musumeci et al.; J. Nutr. Biochem. 2013, 24, 2064-2075. } \\
\text { Lopez; PM R 2012, 4, S155-S168. } \\
\text { Bohlooli et al.; J. Clin. Rheumatol. 2012, 18, 99-101. }\end{array}$ & $\begin{array}{l}\text { Olive oil phenolic } \\
\text { compounds, MUFAs } \\
(500-2000 \mathrm{mg} / \mathrm{d})\end{array}$ & +++ & ++ & + & - & + \\
\hline $\begin{array}{l}\text { Lieber and Packer; Am. J. Clin. Nutr. 2002, 76, 1148S-1150S. } \\
\text { Hosea Blewett; Crit. Rev. Food Sci. Nutr. 2008, 48, 458-463. } \\
\text { Kon et al.; Knee Surg. Sports Traumatol. Arthrosc. 2012, 20, } \\
\text { 436-449. } \\
\text { Lopez; PM R 2012, 4, S155-S168. }\end{array}$ & $\begin{array}{c}\text { Methionine } \\
(800-1200 \mathrm{mg} / \mathrm{d})\end{array}$ & - & +++ & + & + & ++ \\
\hline $\begin{array}{l}\text { Lugo et al.; Nutr. J. 2016, 15, } 14 . \\
\text { Gupta et al.; J. Anim. Physiol. Anim. Nutr. 2012, 96, 770-777. } \\
\text { Zhu et al.; Clin. Immunol. 2007, 122, 7584. } \\
\text { Park et al.; Mod. Rheumatol. 2009, 19, 581-589. } \\
\text { Lopez; PM R 2012, 4, S155-S168. }\end{array}$ & $\begin{array}{l}\text { Undenatured type II } \\
\text { collagen }(40 \mathrm{mg} / \mathrm{d})\end{array}$ & + & - & + & +++ & +++ \\
\hline
\end{tabular}


Table 1. Cont.

\begin{tabular}{|c|c|c|c|c|c|c|}
\hline \multirow[b]{2}{*}{ Analyzed Articles } & \multirow[b]{2}{*}{ Nutraceuticals } & \multicolumn{5}{|c|}{ Potential Role } \\
\hline & & Antiinflammatory & $\begin{array}{c}\text { Redox } \\
\text { Balance/Antioxidant }\end{array}$ & Anabolic & Anticatabolic & $\begin{array}{l}\text { Structural } \\
\text { Substrates }\end{array}$ \\
\hline $\begin{array}{l}\text { Lippiello et al.; Evid. Based Complement Alternat. Med. 2008, 5, } \\
\text { 191-197. } \\
\text { Henrotin et al.; J. Rheumatol. 2003, 30, 1825-1834. } \\
\text { Hong et al.; Carcinogenesis 2004, 25, 1671-1679. } \\
\text { Shakibaei et al.; Biochem. Pharmacol. 2007, 73, 1434-1445. } \\
\text { Shakibaei et al.; Genes Nutr. 2011, 6, 171-179. } \\
\text { Saw et al.; Biochem. Pharmacol. 2010, 79, 421-430. } \\
\text {-Siddiqui; Indian J. Pharm. Sci. 2011, 73, 255-261. } \\
\text { Abdel-Tawab et al.; Clin. Pharmacokinet. 2011, 50, 349-369. } \\
\text { Kimmatkar et al.; Phytomedicine 2003, 10, 3-7. } \\
\text { Badria et al.; Altern. Complement. Ther. 2002, 8, 341-348. } \\
\text { Visioli et al.; Crit. Rev. Food Sci. Nutr. 2011, 51, 524546. } \\
\text { Fraga and Oteiza; Free Radic. Biol. Med. 2011, 51, 813-823. } \\
\text { González et al.; Crit. Rev. Food Sci. Nutr. 2011, 51, 331-362. } \\
\text { Russo et al.; Biochem. Pharmacol. 2012, 83, 6-15. } \\
\text { Ahmed et al.; J. Pharmacol. Exp. Ther. 2004, 308, 767-773. } \\
\text { Murakami et al.; Biofactors 2007, 30, 179-192. } \\
\text { Ahmed; Arthritis Res. Ther. 2010, 12, 208. } \\
\text { Messina et al.; Exp. Neurol. 2009, 220, 349-358. } \\
\text { Adhikari et al.; Indian J. Biochem. Biophys. 2011, 48, 275-282. } \\
\text { Tseng-Crank et al.; J. Diet. Suppl. 2010, 7, 253-272. } \\
\text { Belcaro et al.; Phytother. Res. 2008, 22, 518-523. } \\
\text { Cisár et al.; Phytother. Res. 2008, 22, 1087-1092. } \\
\text { Schulze-Tanzil et al.; Arzneimittelforschung 2004, 54, 213-220. } \\
\text { Fiebich et al.; Phytother. Res. 2011, 10, 36-45. } \\
\text { Wegener and Lupke; Phytother. Res. 2003, 17, 1165-1172. } \\
\text { Gagnier et al.; BMC Complement. Altern. Med. 2004, 4, 13-23. } \\
\text { Brien et al.; Evid. Based Complement. Altern. Med. 2004, 1, } \\
\text { 251-257. } \\
\text { Tilwe et al.; J. Assoc. Physicians. India 2001, 49, 617-621. } \\
\text { Semwal et al.; Phytochemistry 2015, 117, 554-568. } \\
\text { Frondoza et al.; In Vitro Cell Dev. Biol. Anim. 2004, 40, 95-101. } \\
\text { Altman and Marcussen; Arthritis. Rheum. 2001, 44, } \\
\text { 2531-2538. }\end{array}$ & $\begin{array}{l}\text { Botanical extracts ASU } \\
\text { (300-600 mg/d); } \\
\text { polyphenols } \\
(300-2000 \mathrm{mg} / \mathrm{d})\end{array}$ & ++ & ++ & + & ++ & ++ \\
\hline
\end{tabular}


Acknowledgments: This study was supported by a Grant-in-Aid provided by FIR 2016, (cod. 314509), University of Catania, Italy. The authors would like to thank Iain Halliday for commenting and making corrections to the paper.

Author Contributions: All authors have made substantial intellectual contributions to the conception and design of the study as well as data acquisition, analysis, and interpretation. Paola Castrogiovanni carried out the study execution, writing, and literature research. Francesca Maria Trovato carried out the manuscript writing and literature research. Houda Nsirand Marta Anna Szychlinska carried out the literature research Carla Loreto carried out the study execution. Giuseppe Musumeci conceived the study design, supervised the manuscript writing, planning, and editing. All authors contributed to data interpretation and manuscript preparation. All authors approved the final submitted version.

Conflicts of Interest: The authors declare no conflict of interest.

\section{Abbreviations}

$\begin{array}{ll}\text { OA } & \text { Osteoarthritis } \\ \text { MRI } & \text { Magnetic resonance imaging } \\ \text { ECM } & \text { Extracellular matrix } \\ \text { MMP } & \text { Matrix metalloproteinases } \\ \text { ROS } & \text { Reactive oxygen species } \\ \text { TGF- } \beta & \text { Transforming growth factor } \beta \\ \text { GAGs } & \text { Glycosaminoglycan glycans } \\ \text { EPA } & \text { Eicosapentaenoic acid } \\ \text { DHA } & \text { Docosahexaenoic acid } \\ \text { HA } & \text { Hyaluronic acid } \\ \text { SAMe } & \text { S-adenosylmethionine } \\ \text { MUFA } & \text { Monounsaturated fatty acid } \\ \text { NSAIDs } & \text { Nonsteroidal anti-inflammatory drugs } \\ \text { UC-II } & \text { Undenatured type II collagen } \\ \text { ASU } & \text { Avocado/soy unsaponifiable } \\ \text { PUFA } & \text { Polyunsaturated fatty acid } \\ \text { RNS } & \text { Reactive nitrogen species }\end{array}$

\section{References}

1. Musumeci, G.; Aiello, F.C.; Szychlinska, M.A.; di Rosa, M.; Castrogiovanni, P.; Mobasheri, A. Osteoarthritis in the XXIst century: Risk factors and behaviours that influence disease onset and progression. Int. J. Mol. Sci. 2015, 16, 6093-6112. [CrossRef] [PubMed]

2. Musumeci, G. The effects of exercise on physical limitations and fatigue in rheumatic diseases. World J. Orthop. 2015, 6, 762-769. [CrossRef] [PubMed]

3. Szychlinska, M.A.; Trovato, F.M.; di Rosa, M.; Malaguarnera, L.; Puzzo, L.; Leonardi, R.; Castrogiovanni, P.; Musumeci, G. Co-expression and co-localization of cartilage glycoproteins CHI3L1 and lubricin in osteoarthritic cartilage: Morphological, immunohistochemical and gene expression profiles. Int. J. Mol. Sci. 2016, 17, 359. [CrossRef] [PubMed]

4. Musumeci, G.; Szychlinska, M.A.; Mobasheri, A. Age-related degeneration of articular cartilage in the pathogenesis of osteoarthritis: Molecular markers of senescent chondrocytes. Histol. Histopathol. 2015, 30, 1-12. [CrossRef] [PubMed]

5. Musumeci, G.; Mobasheri, A.; Trovato, F.M.; Szychlinska, M.A.; Imbesi, R.; Castrogiovanni, P. Post-operative rehabilitation and nutrition in osteoarthritis. F1000Research 2016, 3, 116. [CrossRef] [PubMed]

6. Castrogiovanni, P.; Musumeci, G. Which is the best physical treatment for osteoarthritis? J. Funct. Morphol. Kinesiol. 2016, 1, 54-68. [CrossRef]

7. Szychlinska, M.A.; Leonardi, R.; Al-Qahtani, M.; Mobasheri, A.; Musumeci, G. Altered joint tribology in osteoarthritis: Reduced lubricin synthesis due to the inflammatory process-New horizons for therapeutic approaches. Ann. Phys. Rehabil. Med. 2016, 59, 149-156. [CrossRef] [PubMed]

8. Reynard, L.N.; Loughlin, J. Genetics and epigenetics of osteoarthritis. Maturitas 2012, 71, 200-204. [CrossRef] [PubMed]

9. Brandt, K.D.; Dieppe, P.; Radin, E.L. Etiopathogenesis of osteoarthritis. Rheum. Dis. Clin. N. Am. 2008, 34, 531-559. [CrossRef] [PubMed] 
10. Musumeci, G. The effect of mechanical loading on articular cartilage. J. Funct. Morphol. Kinesiol. 2016, 1, 154-161. [CrossRef]

11. Aiello, F.C.; Trovato, F.M.; Szychlinska, M.A.; Imbesi, R.; Castrogiovanni, P.; Borzì, F.; Loreto, C.; Musumeci, G. Molecular links between diabetes and osteoarthritis: The role of physical activity. Curr. Diabetes Rev. 2015. [PubMed]

12. Henrotin, Y.; Lambert, C.; Couchourel, D.; Ripoll, C.; Chiotelli, E. Nutraceuticals: Do they represent a new era in the management of osteoarthritis?-A narrative review from the lessons taken with five products. Osteoarthr. Cartil. 2011, 19, 1-21. [CrossRef] [PubMed]

13. Roddy, E.; Doherty, M. Guidelines for management of osteoarthritis published by the American College of Rheumatology and the European League against Rheumatism: Why are they so different? Rheum. Dis. Clin. N. Am. 2003, 29, 717-731. [CrossRef]

14. Lorenz, H.; Richter, W. Osteoarthritis: Cellular and molecular changes in degenerating cartilage. Prog. Histochem. Cytochem. 2006, 40, 135-163. [CrossRef] [PubMed]

15. Musumeci, G.; Loreto, C.; Imbesi, R.; Trovato, F.M.; di Giunta, A.; Lombardo, C.; Castorina, S.; Castrogiovanni, P. Advantages of exercise in rehabilitation, treatment and prevention of altered morphological features in knee osteoarthritis. A narrative review. Histol. Histopathol. 2014, 29, 707-719. [PubMed]

16. Miosge, N.; Hartmann, M.; Maelicke, C.; Herken, R. Expression of collagen type I and type II in consecutive stages of human osteoarthritis. Histochem. Cell Biol. 2004, 122, 229-236. [CrossRef] [PubMed]

17. Shibakawa, A.; Aoki, H.; Masuko-Hongo, K.; Kato, T.; Tanaka, M.; Nishioka, K.; Nakamura, H. Presence of pannus-like tissue on osteoarthritic cartilage and its histological character. Osteoarthr. Cartil. 2003, 11, 133-140. [CrossRef] [PubMed]

18. Mankin, H.J.; Dorfman, H.; Lippiello, L.; Zarins, A. Biochemical and metabolic abnormalities in articular cartilage from osteoarthritic human hips. II. Correlation of morphology with biochemical and metabolic data. J. Bone Jt. Surg. Am. 1971, 53, 523-537. [CrossRef]

19. Sakakibara, Y.; Miura, T.; Iwata, H.; Kikuchi, T.; Yamaguchi, T.; Yoshimi, T.; Itoh, H. Effect of high-molecular weight sodium hyaluronate on immobilized rabbit knee. Clin. Orthop. 1994, 299, 282-292. [CrossRef]

20. Le Graverand, M.P.; Eggerer, J.; Vignon, E.; Otterness, I.G.; Barclay, L.; Hart, D.A. Assessment of specific mRNA levels in cartilage regions in a lapine model of osteoarthritis. J. Orthop. Res. 2002, 20, 535-544. [CrossRef]

21. Kraus, V.B.; Huebner, J.L.; Stabler, T.; Flahiff, C.M.; Setton, L.A.; Fink, C.; Vilim, V.; Clark, A.G. Ascorbic acid increase the severity of spontaneous knee osteoarthritis in a guinea pig model. Arthritis Rheum. 2004, 50, 1822-1831. [CrossRef] [PubMed]

22. Kraus, V.B.; Huebner, J.L.; DeGroot, J.; Bendele, A. The OARSI histopathology initiative-recommendations for histological assessments of osteoarthritis in the guinea pig. Osteoarthr. Cartil. 2010, 18, S35-S52. [CrossRef] [PubMed]

23. Pauli, C.; Grogan, S.P.; Patil, S.; Otsuki, S.; Hasegawa, A.; Koziol, J.; Lotz, M.K.; D'Lima, D.D. Macroscopic and histopathologic analysis of human knee menisci in aging and osteoarthritis. Osteoarthr. Cartil. 2011, 19, 1132-1141. [CrossRef] [PubMed]

24. Musumeci, G.; Castrogiovanni, P.; Trovato, F.M.; Di Giunta, A.; Loreto, C.; Castorina, S. Microscopic and macroscopic anatomical features in healthy and osteoarthritic knee cartilage. OA Anat. 2013, 1, 30. [CrossRef]

25. Musumeci, G.; Loreto, C.; Castorina, S.; Imbesi, R.; Leonardi, R.; Castrogiovanni, P. Current concepts in the treatment of cartilage damage. A review. Ital. J. Anat. Embryol. 2013, 118, 189-203. [PubMed]

26. Musumeci, G.; Loreto, C.; Castorina, S.; Imbesi, R.; Leonardi, R.; Castrogiovanni, P. New perspectives in the treatment of cartilage damage. Poly(ethylene glycol) diacrylate (PEGDA) scaffold. A review. Ital. J. Anat. Embryol. 2013, 118, 204-210. [PubMed]

27. Musumeci, G.; Trovato, F.M.; Pichler, K.; Weinberg, A.M.; Loreto, C.; Castrogiovanni, P. Extra-virgin olive oil diet and mild physical activity prevent cartilage degeneration in an osteoarthritis model: An in vivo and in vitro study on lubricin expression. J. Nutr. Biochem. 2013, 24, 2064-2075. [CrossRef] [PubMed]

28. Ruan, M.Z.; Patel, R.M.; Dawson, B.C.; Jiang, M.M.; Lee, B.H. Pain, motor and gait assessment of murine osteoarthritis in a cruciate ligament transection model. Osteoarthr. Cartil. 2013, 21, 1355-1364. [CrossRef] [PubMed] 
29. Pritzker, K.P.; Aigner, T. Terminology of osteoarthritis cartilage and bone histopathology-A proposal for a consensus. Osteoarthr. Cartil. 2010, 18, S7-S9. [CrossRef] [PubMed]

30. Egloff, C.; Hügle, T.; Valderrabano, V. Biomechanics and pathomechanisms of osteoarthritis. Swiss Med. Wkly. 2012, 142, w13583. [CrossRef] [PubMed]

31. Boe, C.; Vangsness, C.T. Fish oil and osteoarthritis: Current evidence. Am. J. Orthop. 2015, 44, 302-305. [PubMed]

32. Hill, C.L.; March, L.M.; Aitken, D.; Lester, S.E.; Battersby, R.; Hynes, K.; Fedorova, T.; Proudman, S.M.; James, M.; Cleland, L.G.; et al. Fish oil in knee osteoarthritis: A randomised clinical trial of low dose versus high dose. Ann. Rheum. Dis. 2016, 75, 23-29. [CrossRef] [PubMed]

33. Gao, S.G.; Zeng, C.; Wei, J.; Wang, Y.L.; Lei, G.H. Paying attention to the safety and efficacy of fish oil in treatment of knee osteoarthritis. Ann. Rheum. Dis. 2016, 75, e13. [CrossRef] [PubMed]

34. Kirkham, S.G.; Samarasinghe, R.K. Review article: Glucosamine. J. Orthop. Surg. 2009, 17, 72-76. [CrossRef]

35. Henrotin, Y.; Mobasheri, A.; Marty, M. Is there any scientific evidence for the use of glucosamine in the management of human osteoarthritis? Arthritis Res. Ther. 2012, 17, 201. [CrossRef] [PubMed]

36. Michel, B.A.; Stucki, G.; Frey, D.; de Vathaire, F.; Vignon, E.; Bruehlmann, P.; Uebelhart, D. Chondroitins 4 and 6 sulfate in osteoarthritis of the knee: A randomized, controlled trial. Arthritis Rheum. 2005, 52, 779-786. [CrossRef] [PubMed]

37. Kahan, A.; Uebelhart, D.; de Vathaire, F.; Delmas, P.D.; Reginster, J.Y. Long-term effects of chondroitin sulfate on knee osteoarthritis: The study on osteoarthritis progression prevention, a two-year, randomized, double- blind, placebo-controlled trial. Arthritis Rheum. 2009, 60, 524-533. [CrossRef] [PubMed]

38. Jackson, C.G.; Plaas, A.H.; Sandy, J.D.; Hua, C.; Kim-Rolands, S.; Barnhill, J.G.; Harris, C.L.; Clegg, D.O. The human pharmacokinetics of oral ingestion of glucosamine and chondroitin sulfate taken separately or in combination. Osteoarthr. Cartil. 2010, 19, 297-302. [CrossRef] [PubMed]

39. Lopez, H.L. Nutritional interventions to prevent and treat osteoarthritis-Part II: Focus on micronutrients and supportive nutraceuticals. PM R 2012, 4, S155-S168. [CrossRef] [PubMed]

40. Clegg, D.O.; Reda, D.J.; Harris, C.L.; Klein, M.A.; O’Dell, J.R.; Hooper, M.M.; Bradley, J.D.; Bingham, C.O., 3rd; Weisman, M.H.; Jackson, C.G.; et al. Glucosamine, chondroitin sulfate, and the two in combination for painful knee osteoarthritis. N. Engl. J. Med. 2006, 354, 795-808. [CrossRef] [PubMed]

41. Gruenwald, J.; Petzold, E.; Busch, R.; Petzold, H.P.; Graubaum, H.J. Effect of glucosamine sulfate with or without omega-3 fatty acids in patients with osteoarthritis. Adv. Ther. 2009, 26, 858-871. [CrossRef] [PubMed]

42. Maneiro, E.; de Andres, M.C.; Ferández-Sueiro, J.L.; Galdo, F.; Blanco, F.J. The biological action of hyaluronan on human osteoarthritic articular chondrocytes: The importance of molecular weight. Clin. Exp. Rheumatol. 2004, 22, 307-312. [PubMed]

43. Adams, M.E.; Lussier, A.J.; Peyron, J.G. A risk-benefit assessment of injections of hyaluronan and its derivatives in the treatment of knee osteoarthritis. Drug Saf. 2000, 23, 115-130. [CrossRef] [PubMed]

44. Balogh, L.; Polyak, A.; Matheetal, D. Absorption, uptake and tissue affinity of high-molecular-weight hyaluronan after oral administration in rats and dogs. J. Agric. Food Chem. 2008, 56, 10582-10593. [CrossRef] [PubMed]

45. Bohlooli, S.; Jastan, M.; Nakhostin-Roohi, B.; Mohammadi, S.; Baghaei, Z. A pilot double-blinded, randomized, clinical trial of topical virgin olive oil versus piroxicam gel in osteoarthritis of the knee. J. Clin. Rheumatol. 2012, 18, 99-101. [CrossRef] [PubMed]

46. Lieber, C.S.; Packer, L. S-Adenosylmethionine: Molecular, biological, and clinical aspects: An introduction. Am. J. Clin. Nutr. 2002, 76, 1148S-1150S. [PubMed]

47. Hosea Blewett, H.J. Exploring the mechanisms behind S-adenosylmethionine (SAMe) in the treatment of osteoarthritis. Crit. Rev. Food Sci. Nutr. 2008, 48, 458-463. [CrossRef] [PubMed]

48. Kon, E.; Filardo, G.; Drobnic, M.; Madry, H.; Jelic, M.; van Dijk, N.; Della Villa, S. Non-surgical management of early knee osteoarthritis. Knee Surg. Sports Traumatol. Arthrosc. 2012, 20, 436-449. [CrossRef] [PubMed]

49. De Silva, V.; El-Metwally, A.; Ernst, E.; Lewith, G.; Macfarlane, G.J.; Arthritis Research UK Working Group on Complementary and Alternative Medicines. Evidence for the efficacy of complementary and alternative medicines in the management of osteoarthritis: A systematic review. Rheumatology 2011, 50, 911-920. [CrossRef] [PubMed] 
50. Najm, W.I.; Reinsch, S.; Hoehler, F.; Tobis, J.S.; Harvey, P.W. S-Adenosyl methionine versus celecoxib for the treatment of osteoarthritis symptoms: A double-blind cross-over trial. BMC Musculoskelet. Disord. 2004, 5, 6. [CrossRef] [PubMed]

51. Lugo, J.P.; Saiyed, Z.M.; Lane, N.E. Efficacy and tolerability of an undenatured type II collagen supplement in modulating knee osteoarthritis symptoms: A multicenter randomized, double-blind, placebo-controlled study. Nutr. J. 2016, 15, 14. [CrossRef] [PubMed]

52. Gupta, R.C.; Canerdy, T.D.; Lindley, J.; Konemann, M.; Minniear, J.; Carroll, B.A.; Hendrick, C.; Goad, J.T.; Rohde, K.; Doss, R.; et al. Comparative therapeutic efficacy and safety of type-II collagen (UC-II ${ }^{\circledR}$ ), glucosamine and chondroitin in arthritic dogs: Pain evaluation by ground force plate. J. Anim. Physiol. Anim. Nutr. 2012, 96, 770-777. [CrossRef] [PubMed]

53. Zhu, P.; Li, X.Y.; Wang, H.K.; Jia, J.F.; Zheng, Z.H.; Ding, J.; Fan, C.M. Oral administration of type-II collagen peptide 250-270 suppresses specific cellular and humoral immune response in collagen-induced arthritis. Clin. Immunol. 2007, 122, 75-84. [CrossRef] [PubMed]

54. Park, K.S.; Park, M.J.; Cho, M.L.; Kwok, S.K.; Ju, J.H.; Ko, H.J.; Park, S.H.; Kim, H.Y. Type II collagen oral tolerance: Mechanism and role in collagen-induced arthritis and rheumatoid arthritis. Mod. Rheumatol. 2009, 19, 581-589. [CrossRef] [PubMed]

55. Lippiello, L.; Nardo, J.V.; Harlan, R.; Chiou, T. Metabolic effects of avocado/soy unsaponifiables on articular chondrocytes. Evid. Based Complement. Altern. Med. 2008, 5, 191-197. [CrossRef] [PubMed]

56. Henrotin, Y.E.; Sanchez, C.; Deberg, M.A.; Piccardi, N.; Guillou, G.B.; Msika, P.; Reginster, J.Y. Avocado/soybean unsaponifiables increase aggrecan synthesis and reduce catabolic and proinflammatory mediator production by human osteoarthritic chondrocytes. J. Rheumatol. 2003, 30, 1825-1834. [PubMed]

57. Hong, J.; Bose, M.; Ju, J.; Ryu, J.H.; Chen, X.; Sang, S.; Lee, M.J.; Yang, C.S. Modulation of arachidonic acid metabolism by curcumin and related $\beta$-diketone derivatives: Effects on cytosolic phospholipase $\mathrm{A}_{2}$, cyclooxygenases and 5-lipoxygenase. Carcinogenesis 2004, 25, 1671-1679. [CrossRef] [PubMed]

58. Shakibaei, M.; John, T.; Schulze-Tanzil, G.; Lehmann, I.; Mobasheri, A. Suppression of NF-kappaB activation by curcumin leads to inhibition of expression of cyclooxygenase-2 and matrix metalloproteinase-9 in human articular chondrocytes: Implications for the treatment of osteoarthritis. Biochem. Pharmacol. 2007, 73, 1434-1445. [CrossRef] [PubMed]

59. Shakibaei, M.; Mobasheri, A.; Buhrmann, C. Curcumin synergizes with resveratrol to stimulate the MAPK signaling pathway in human articular chondrocytes in vitro. Genes Nutr. 2011, 6, 171-179. [CrossRef] [PubMed]

60. Saw, C.L.; Huang, Y.; Kong, A.N. Synergistic anti-inflammatory effects of low doses of curcumin in combination with polyunsaturated fatty acids: Docosahexaenoic acid or eicosapentaenoic acid. Biochem. Pharmacol. 2010, 79, 421-430. [CrossRef] [PubMed]

61. Siddiqui, M.Z. Boswellia serrata, a potential antiinflammatory agent: An overview. Indian J. Pharm. Sci. 2011, 73, 255-261. [PubMed]

62. Abdel-Tawab, M.; Werz, O.; Schubert-Zsilavecz, M. Boswellia serrata: An overall assessment of in vitro, preclinical, pharmacokinetic and clinical data. Clin. Pharmacokinet. 2011, 50, 349-369. [CrossRef] [PubMed]

63. Kimmatkar, N.; Thawani, V.; Hingorani, L.; Khiyani, R. Efficacy and tolerability of Boswellia serrata extract in treatment of osteoarthritis of knee: A randomized double blind placebo controlled trial. Phytomedicine 2003, 10, 3-7. [CrossRef] [PubMed]

64. Badria, F.A.; El-Farahaty, T.; Shabana, A.A.; Hawas, S.A.; El-Batoty, M.F. Boswellia-curcumin preparation for treating knee osteoarthritis. Altern. Complement. Ther. 2002, 8, 341-348. [CrossRef] [PubMed]

65. Visioli, F.; de La Lastra, C.A.; Andres-Lacueva, C.; Aviram, M.; Calhau, C.; Cassano, A.; D'Archivio, M.; Faria, A.; Favé, G.; Fogliano, V.; et al. Polyphenols and human health: A prospectus. Crit. Rev. Food Sci. Nutr. 2011, 51, 524-546. [CrossRef] [PubMed]

66. Fraga, C.G.; Oteiza, P.I. Dietary flavonoids: Role of (-)-epicatechin and related procyanidins in cell signaling. Free Radic. Biol. Med. 2011, 51, 813-823. [CrossRef] [PubMed]

67. González, R.; Ballester, I.; López-Posadas, R.; Suárez, M.D.; Zarzuelo, A.; Martínez-Augustin, O.; Sánchez de Medina, F. Effects of flavonoids and other polyphenols on inflammation. Crit. Rev. Food Sci. Nutr. 2011, 51, 331-362. [CrossRef] [PubMed]

68. Russo, M.; Spagnuolo, C.; Tedesco, I.; Bilotto, S.; Russo, G.L. The flavonoid quercetin in disease prevention and therapy: Facts and fancies. Biochem. Pharmacol. 2012, 83, 6-15. [CrossRef] [PubMed] 
69. Ahmed, S.; Wang, N.; Lalonde, M.; Goldberg, V.M.; Haqqi, T.M. Green tea polyphenol epigallocatechin-3-gallate (EGCG) differentially inhibits interleukin-1 $\beta$-induced expression of matrix metalloproteinase-1 and -13 in human chondrocytes. J. Pharmacol. Exp. Ther. 2004, 308, 767-773. [CrossRef] [PubMed]

70. Murakami, A.; Song, M.; Katsumata, S.; Uehara, M.; Suzuki, K.; Ohigashi, H. Citrus nobiletin suppresses bone loss in ovariectomized ddY mice and collagen-induced arthritis in DBA/1J mice: Possible involvement of receptor activator of NF-KB ligand (RANKL)-induced osteoclastogenesis regulation. Biofactors 2007, 30 , 179-192. [CrossRef] [PubMed]

71. Ahmed, S. Green tea polyphenol epigallocatechin 3-gallate in arthritis: Progress and promise. Arthritis Res. Ther. 2010, 12, 208. [CrossRef] [PubMed]

72. Messina, S.; Bitto, A.; Aguennouz, A.M.; Mazzeo, A.; Migliorato, A.; Polito, F.; Irrera, N.; Altavilla, D.; Vita, G.L.; Russo, M.; et al. Flavocoxid inhibits NFkappaB, MAPKs and COX/5-LOX pathways and improves muscle function and morphology in mdx mice: A comparison study with methylprednisolone. Exp. Neurol. 2009, 220, 349-358. [CrossRef] [PubMed]

73. Adhikari, S.; Tilak, J.C.; Devasagayam, T.P. Free radical reactions of a naturally occurring flavone baicalein and possible mechanisms towards its membrane protective properties. Indian J. Biochem. Biophys. 2011, 48, 275-282. [PubMed]

74. Tseng-Crank, J.; Sung, S.; Jia, Q.; Zhao, Y.; Burnett, B.; Park, D.R.; Woo, S.S. A medicinal plant extract of Scutellaria baicalensis and Acacia catechu reduced LPS-stimulated gene expression in immune cells: A comprehensive genomic study using QPCR, ELISA, and microarray. J. Diet. Suppl. 2010, 7, 253-272. [CrossRef] [PubMed]

75. Belcaro, G.; Cesarone, M.R.; Errichi, S.; Zulli, C.; Errichi, B.M.; Vinciguerra, G.; Ledda, A.; di Renzo, A.; Stuard, S.; Dugall, M.; et al. Treatment of osteoarthritis with Pycnogenol. The SVOS (San Valentino Osteo-arthrosis Study). Evaluation of signs, symptoms, physical performance and vascular aspects. Phytother. Res. 2008, 22, 518-523. [CrossRef] [PubMed]

76. Cisár, P.; Jány, R.; Waczulíková, I.; Sumegová, K.; Muchová, J.; Vojtassák, J.; Duraćková, Z.; Lisý, M.; Rohdewald, P. Effect of pine bark extract (Pycnogenol) on symptoms of knee osteoarthritis. Phytother. Res. 2008, 22, 1087-1092. [CrossRef] [PubMed]

77. Schulze-Tanzil, G.; Hansen, C.; Shakibaei, M. Effect of a Harpagophytum procumbens DC extract on matrix metalloproteinases in human chondrocytes in vitro. Arzneimittel-Forschung 2004, 54, 213-220. [PubMed]

78. Fiebich, B.L.; Muñoz, E.; Rose, T.; Weiss, G.; McGregor, G.P. Molecular targets of the anti-inflammatory Harpagophytum procumbens (Devil's claw): Inhibition of TNF $\alpha$ and COX-2 gene expression by preventing activation of AP-1. Phytother. Res. 2011, 10, 36-45.

79. Wegener, T.; Lupke, N.P. Treatment of patients with arthrosis of hip or knee with an aqueous extract of devil's claw (Harpagophytum procumbens DC). Phytother. Res. 2003, 17, 1165-1172. [CrossRef] [PubMed]

80. Gagnier, J.J.; Chrubasik, S.; Manheimer, E. Harpagophytum procumbens for osteoarthritis and low back pain: A systematic review. BMC Complement. Altern. Med. 2004, 4, 13. [CrossRef] [PubMed]

81. Chantre, P.; Cappelaere, A.; Leblan, D.; Guedon, D.; Vandermander, J.; Fournie, B. Efficacy and tolerance of Harpagophytum procumbens versus diacerhein in treatment of osteoarthritis. Phytomedicine 2000, 7, 177-183. [CrossRef]

82. Brien, S.; Lewith, G.; Walker, A.; Hicks, S.M.; Middleton, D. Bromelain as a treatment for osteoarthritis: A review of clinical studies. Evid. Based Complement. Altern. Med. 2004, 1, 251-257. [CrossRef] [PubMed]

83. Tilwe, G.H.; Beria, S.; Turakhia, N.H.; Daftary, G.V.; Schiess, W. Efficacy and tolerability of oral enzyme therapy as compared to diclofenac in active osteoarthrosis of knee joint: An open randomized controlled clinical trial. J. Assoc. Physicians India 2001, 49, 617-621. [PubMed]

84. Semwal, R.B.; Semwal, D.K.; Combrinck, S.; Viljoen, A.M. Gingerols and shogaols: Important nutraceutical principles from ginger. Phytochemistry 2015, 117, 554-568. [CrossRef] [PubMed]

85. Frondoza, C.G.; Sohrabi, A.; Polotsky, A.; Phan, P.V.; Hungerford, D.S.; Lindmark, L. An in vitro screening assay for inhibitors of proinflammatory mediators in herbal extracts using human synoviocyte cultures. In Vitro Cell. Dev. Biol. Anim. 2004, 40, 95-101. [CrossRef]

86. Altman, R.D.; Marcussen, K.C. Effects of a ginger extract on knee pain in patients with osteoarthritis. Arthritis Rheum. 2001, 44, 2531-2538. [CrossRef] 
87. Bliddal, H.; Rosetzky, A.; Schlichting, P.; Weidner, M.S.; Andersen, L.A.; Ibfelt, H.H.; Christensen, K.; Jensen, O.N.; Barslev, J. A randomized, placebo-controlled, cross-over study of ginger extracts and ibuprofen in osteoarthritis. Osteoarthr. Cartil. 2000, 8, 9-12. [CrossRef] [PubMed]

88. Wigler, I.; Grotto, I.; Caspi, D.; Yaron, M. The effects of Zintona EC (a ginger extract) on symptomatic gonarthritis. Osteoarthr. Cartil. 2003, 11, 783-789. [CrossRef]

(C) 2016 by the authors; licensee MDPI, Basel, Switzerland. This article is an open access article distributed under the terms and conditions of the Creative Commons Attribution (CC-BY) license (http:/ / creativecommons.org/licenses/by/4.0/). 